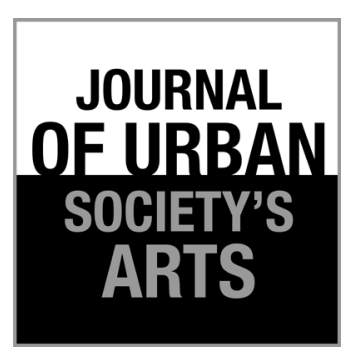

Volume 8 Number 1, April 2021: 49-60

\section{Redesign the Lampit to Reduce the Workload in Dusun Semaja, Tabanan, Bali}

\section{Nyoman Artayasa}

Interior Design, Fine Arts and Design Faculty

Indonesian Institute of The Arts Denpasar

Nusa Indah street Denpasar, Bali, Indonesia

Email: artayasa01@yahoo.com; HP.: +62 8123836186

\begin{abstract}
Lampit is one of the traditional means of cultivating rice fields, which functions to level the land for planting rice. The operation of lampit can increase the work pulse up to $50 \%$ above the resting pulse and is included in the category of moderate to heavy workloads. At the end of the operation of lampit, it may cause complaints, especially on the buttocks and back, which is caused by the small and hardness of the lampit rod. There was an improvement to the lampit seating design by adding foam pads and adjusting the pressure lever found on the lampit stem to overcome this problem. This research is an experimental study using the same subject design, selected 30 research subjects from farmers in Dusun Semaja Antosari Tabanan Bali. The workload is evaluated based on the work pulse measured using the ten pulses method. In addition, the pulse was measured before and after the improvement of the lampit design. The data compared were the mean values before and after improvement, which were analyzed using paired t test $(\alpha=0.05)$. The result is a significant decrease in the work rate of $19.35 \%(\mathrm{p}<0.05)$. Thus, it can be concluded that the improved design of the lampit can reduce the workload. Therefore, farmers should continue using and perfecting the improved lampit.
\end{abstract}

Keywords: workload; pulse; lampit

\begin{abstract}
ABSTRAK
Desain Ulang Lampit untuk Mengurangi Beban Kerja di Dusun Semaja, Tabanan, Bali. Lampit adalah salah satu alat tradisional pengolahan sawah, yang berfungsi untuk meratakan tanah sawah yang akan ditanami padi. Pengoperasian lampit dapat meningkatkan rerata denyut nadi kerja mencapai $50 \%$ di atas denyut nadi istirahat dan termasuk pada katagori beban kerja sedang-dengan berat. Pada Akhir pengoperasian lampit, menimbulkan keluhan terutama pada bagian pantat dan punggung, yang disebabkan oleh kecil dan kerasnya batang lampit. Untuk mengatasi keadaan tersebut, diadakan perbaikan pada desain tempat duduk lampit dengan penambahan bantalan busa dan penyesuaian tuas tekan yang terdapat pada batang lampit. Penelitian ini merupakan penelitian eksperimental yang menggunakan rancangan sama subjek, dipilih tiga puluh orang subjek penelitian dari petani yang ada di Dusun Semaja Antosari Tabanan Bali. Beban kerja dievaluasi atas dasar denyut nadi kerja yang diukur dengan menggunakan metode sepuluh denyut, yang diukur sebelum dan sesudah perbaikan desain lampit. Data yang dibandingkan adalah rerata nilai sebelum dan setelah perbaikan, yang dianalisa dengan mengunakan uji t paired test $(\alpha=0.05)$. Hasilnya adalah terdapat penurunan denyut nadi kerja secara bermakna yaitu sebesar 19,35\% ( $<<0.05)$. Dengan demikian dapat disimpulkan, bahwa dengan perbaikan desain lampit dapat menurunkan beban kerja, oleh kerena itu disarankan kepada petani untuk tetap mempergunakan dan menyempurnakan lampit yang telah diperbaiki.
\end{abstract}

Kata kunci: beban kerja; denyut nadi; lampit 


\section{Introduction}

The condition of the rice fields which are hilly and the area of rice fields is not that much, causing the rare use of modern rice processing tools. Working plowing the fields in hilly rice fields and the area of the rice fields is not that big, causing the rare use of modern rice processing tools. The traditional Balinese rice plow tool is still suitable and effective. This situation causes traditional rice processing tools to be used very often, one of which is lampit. Lampit is a plow tool for leveling the land, which is pulled by two cows, where the process of leveling the land is the final process before planting rice. The operation is carried out by sitting on the lampit stem, with the hand holding the lampit stem for balance and also pressing so that the leveling of the paddy soil is as desired. The lampit operator occasionally gets out of his seat to move this tool from one paddy field to another, while tidying the land that has just been leveled by lampit. The way of operating this lampit is generally quite natural, but if you pay close attention to it, at the end of the implementation of this work, the operator or farmer will feel complaints in the musculoskeletal system, especially on the buttocks and back. Complaints that arise in the area vary from pain to blisters and blisters (calluses). This complaint could be caused by the too small and hard rod of the lampit which was used as a seat during the operation of the appliance. The $6 \mathrm{~cm}$ size of the lampit stem which is used as a seat is not able to support the weight distribution of the operator perfectly. The heaviest body weight when sitting lies in the ischial tuberosities. When sitting on a lampit stem, physiologically the body weight is supported only by one of the ischial tuberosities or by the middle between the two protrusions of the ischial tuberosities. According to MS \& Ej, (1992), seating should be designed with attention to the distribution of body weight, especially in the buttocks area and around the ischial tuberosities. Under these circumstances, the workload of farmers or operators when operating the lamps is increased from the actual workload.

Research on plowing the fields carried out in India by De and Sen (1986), reported that the work was included in the heavy to moderate workload category, with a pulse ranging from 110-130 beats/ minute. Meanwhile, Santiana et al., (2014) state that the workload measured by the work pulse shows that the workload during rice cultivation is included in the very heavy work category with a pulse rate of 129.88 beats/minute. Salokhe $\&$ Mamansari (1995) (Salokhe \& Mamansari, 1995) state that improving the rice field processing process, modifying tools or improving work attitudes is a must in order to reduce the workload of farmers in Thailand.

For Indonesia, especially Bali, research on the workload in cultivating rice fields has been carried out by Santiana et al., 2018 et al., (2018), which is based on WBGT and\% CVL. The results show that rice processing work is included in the category of moderate to heavy workload and requires a 50\% work arrangement and $50 \%$ even up to $25 \%$ to $75 \%$ rest from eight hours of work carried out in one day. It is understandable then, that the ngelampit work carried out in Dusun Semaja is mostly carried out in the morning between \pm 07.00 and \pm 11.00 .

As previously described, the farmer when the lampit operation is carried out by bending and sitting on a lampit stem with a width of 6 $\mathrm{cm}$ and a pressure lever height of $43.3 \mathrm{~cm}$, causes additional loads and also causes complaints to the musculoskeletal system. The emergence of complaints and the presence of additional workloads causes the activities of farmers after finishing operating the clay to be disturbed, so that the activities that are usually carried out after working in the fields cannot be carried out properly.

To reduce the workload, especially in the buttocks area, there was a redesign of the seats, by adding foam pads and adjusting the height of the pressure lever to $61.3 \mathrm{~cm}$ on the rod. This redesign is carried out because it has several advantages, namely technically more efficient, economically more profitable, socio-culture does not cause turmoil, does not damage the environment, saves energy, does not cause the possibility of new diseases, in addition to the rare research on workload and complaints of the musculoskeletal system that arise when operating the lampit. The operation is more 
often carried out by men, while in some other rice fields processing can be carried out by women or men. Based on this, this research was conducted on male farmers. This type of design research is very rarely done, most research on design, especially interior design, only talks about interior design in general, for example about the direction of view, floors, walls and ceilings (Sholahuddin, 2014), and others mostly researching aesthetics related to interior design or architecture (Gorgi, 2019).

\section{Methodology}

This type of research is an experiment with the same subject design (treatment by subject). In this study, it is necessary to have washing out which is useful for eliminating the effects of previous treatments so as not to leave an effect or response: $\mathrm{A} 1 \rightarrow \mathrm{L} \rightarrow \mathrm{A}^{\prime}$ W $\mathrm{W} \quad \mathrm{A} 2 \rightarrow \mathrm{L} 1 \rightarrow \mathrm{A} 2 "$

$\mathrm{A} 1$ and $\mathrm{A1}$ ' shows the data collection carried out on lampit before repairing:

Workload is measured by recording the change in pulse rate, it is carried out for a moment to start work or at rest (A1) and after working for 1 hour, 2 hours, 3 hours and 4 hours, the pulse rate starts up to the fifth minute then the mean is searched (A1'). With the value before repair is the difference between $\mathrm{A} 1$ and $\mathrm{A1}$ '; on lampit which has not been redesigned.

A2 and A2" show the data collection that was carried out on the lampit after repairs to:

Workload is measured by recording the change in pulse rate, it is carried out at a time when starting work or at rest (A2) and after working for 1 hour, 2 hours, 3 hours and 4 hours, the recovery pulse is up to the fifth minute then the mean is searched (A2"). With the value after improvement is the difference between A2 and A2"; on lampit which has been redesigned.

$\mathrm{W}$ is washing out, which is an attempt to remove the effects of using the lamp before repair so as not to leave an effect or response. The implementation is carried out for a minimum of three days.

The data were processed descriptively, in order to obtain the mean and standard deviation of changes in work pulse, recovery pulse and scores of musculoskeletal system disorders in treatment and control. The data normality test was carried out by the Kolmogorov-Smirnov (KS) test (goodness of fit test). (Usman, 2020); (Kirkwood \& Sterne, 2010). The data were normally distributed, followed by a parametric statistical test. To find out the difference in workload between the unedesigned lampits and after being redesigned, the statistical test was analyzed using the $t$ test on the one-tail test, with a significance level of $=0.05$, in this case it was compared between the mean pulse of the farmers operating the lamp before redesign or control with the average pulse rate of the farmer who operates the lamp that has been designed or treated.

Some of the variables are explained as follows: Workload is the load that comes from the work that is being done, which has special characteristics for everyone. Measurement of workload is done by measuring the increase in pulse rate per minute measured by time: rest, work and recovery using the 10 pulse method. The 10 pulse method is a method by palpation of the radial artery of the left hand, which counts how long it takes from the first pulse to the eleventh pulse, the result is in seconds. For example, the length of time is 10 beats $=6$ seconds, then the pulse per minute $=$ $\frac{60}{6} \times 10=100$ pulses. Work pulse measurement is carried out when the subject performs the lampit operation by sitting on the lampit stem.

1. Resting pulse rate is the pulse per minute measured in a resting state, by sitting for 10 minutes before performing the lampit operation with the ten pulse method.

2. Recovery pulse rate is the pulse measured after completion of work, namely at the 1, 2, 3, 4 and 5 minutes measured by the ten pulse method.

3. The lampit before the repair is: a lampit (a paddy plow tool) which is usually used by Dusun Semaja farmers to level their fields, with a seat height and a pressure lever of $43.3 \mathrm{~cm}$.

4. The lampit after the design improvement is the one that has been added to the foam pad and adjust the height of the pressure lever to 61.3 $\mathrm{cm}$.

The population in this study were 54 male farmers in Dusun Semaja, Antosari Village, 
Tabanan Regency who worked during the planting season in the February - November 2018 period, in total 54 people with an age range of 25 - 60 years.

\section{Discussion}

The population in this study were farmers in Dusun Semaja who were in the process of cultivating rice fields during the planting season February-July and September-November 2018. The operation of lampit was generally carried out by men, as was the case in Dusun Semaja. The total population is 60 people with an age range of 24-58 years. Subjects were male farmers, who met the requirements and continued to participate until the study was completed as many as 30 people. The characteristics of the research subjects regarding age, weight, height, anthropometric data and systolic and diastolic blood pressure are presented in the table 1.

From table 1, several things can be stated as follows: a) the mean age is 33.334 .83 with a range of 24-40 years which can be categorized as the productive age carrying out work; b) mean height $1643.72 \mathrm{~cm}$ with a mean body weight of 561.67 $\mathrm{kg}$ including the ideal height and weight according to the Broca index; c) average popliteal height of 43 $1.67 \mathrm{~cm}$, in accordance with the anthropometry of Indonesians in general; d) reach length and elbow

Table 1. Characteristics of 30 male farmers in Dusun Semaja. In average, standard and range deviations.

\begin{tabular}{lccc}
\hline No Variable & Average & SI & $\begin{array}{c}\text { Range } \\
\text { Deviation }\end{array}$ \\
\hline 1. Age & 33,33 & 4,83 & $24-40$ \\
2. Height $(\mathrm{cm})$ & 164 & 3,72 & $155-172$ \\
3. Weight $(\mathrm{kg})$ & 56 & 1,67 & $49-70$ \\
4. Anthropometric data $(\mathrm{cm})$ & & & \\
$\quad$ - popliteal height & 43 & 1,67 & $40-46$ \\
- hand & 62 & 2,20 & $59-67$ \\
$\quad$ - height of elbow & 100,83 & 3,39 & $90-106,40$ \\
\hline
\end{tabular}

height $622.20 ; 1003.39 \mathrm{~cm}$, according to the anthropometry of Indonesians in general.

\section{Working Pulse}

Data collection on working pulse and musculoskeletal disorders before and after work, both in control and treatment, and the data are presented in the table 2 .

From table 2 it can be stated that: in the control, there is an increase in the work pulse from the resting pulse and it is included in the heavy workload category. The average work pulse per hour for four hours did not differ significantly. Thus, it can be said that during the operation of the lampit, the farmers were exposed to a heavy workload. Whereas in the treatment there was a decrease in the increase in the work pulse rate from the moderate working category to approaching the lower limit of heavy work (110-130). The average working pulse per hour for four hours was significantly different, especially in the first hour and the last hour. Thus, in the treatment, it can be said that there is a decrease in workload during the lampit operation. Meanwhile, between control and treatment there were significant differences. For more details, it can be seen in Graph 1.

From table 3 it can be stated that there was a very significant difference in work pulse in control and treatment with $\mathrm{t}=7.75$ and $\mathrm{t}=9.18(\mathrm{p} \mathrm{0.01})$; Likewise, the mean difference in work pulse and

Table 2. Average working pulse per hour, in control and treatment of 30 male farmers in Dusun Semaja.

\begin{tabular}{lcccc}
\hline \multirow{2}{*}{ Groups } & \multicolumn{4}{c}{ Working Pulse (pulse/minutes) } \\
\cline { 2 - 5 } & 1 hour & 2 hours & 3 hours & 4 hours \\
\hline Control & $110,3 \pm 10,72$ & $110,3 \pm 10,72$ & $111,4 \pm 10,6$ & $107,4 \pm 7,47$ \\
Treatment & $107,4 \pm 9,07$ & $105 \pm 9,8$ & $101,5 \pm 9,1$ & $99,8 \pm 7,45$ \\
t-test paired & 2,94 & 5,01 & 5,95 & 5,44 \\
P & 0,006 & 0,000 & 0,000 & 0,000 \\
\hline
\end{tabular}
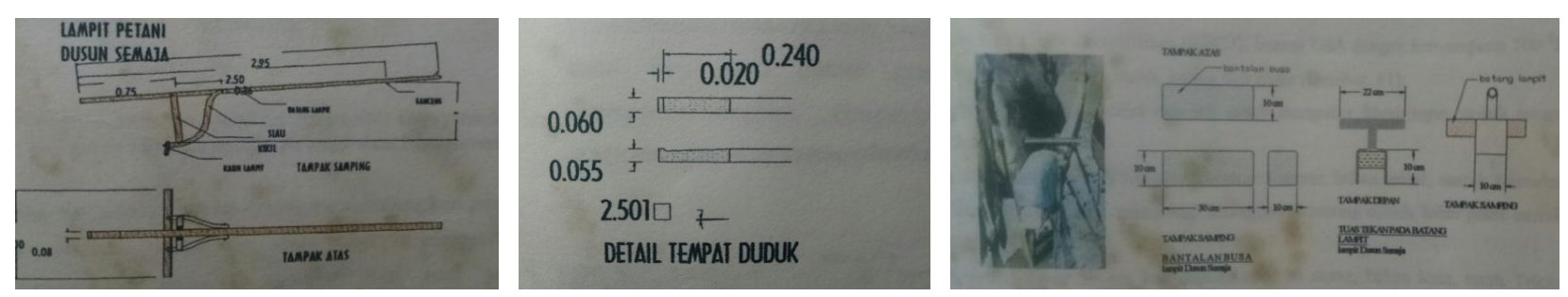

Figure 1. Lampit dusun Semaja farmers. 
musculoskeletal disorders with $\mathrm{t}=6.73$ and 8.84 (p 0.01). Meanwhile, ECPT, ECMP, \% CVL and WBGT are shown in the table 4.

From table 4, several things can be conveyed as follows:

1. The average of ECPT in control 17.138 .87 and treatment 17.67 7.30, while ECPM in control 24.077 .39 and treatment 21.27 5.68. If you pay attention to ECPM before treatment and after treatment, both of them are greater than ECPT in both control and treatment, this means that the heat that occurs is due to metabolic processes caused by active muscles that are more dominant.

2. The average of \% CVL in control 59.678 .87 and treatment 48.3714 .16 , there is a significant difference with $\mathrm{t}$ count $=14.16, \mathrm{p} 0.05$, this means that there is a decrease in cardiovascular load.

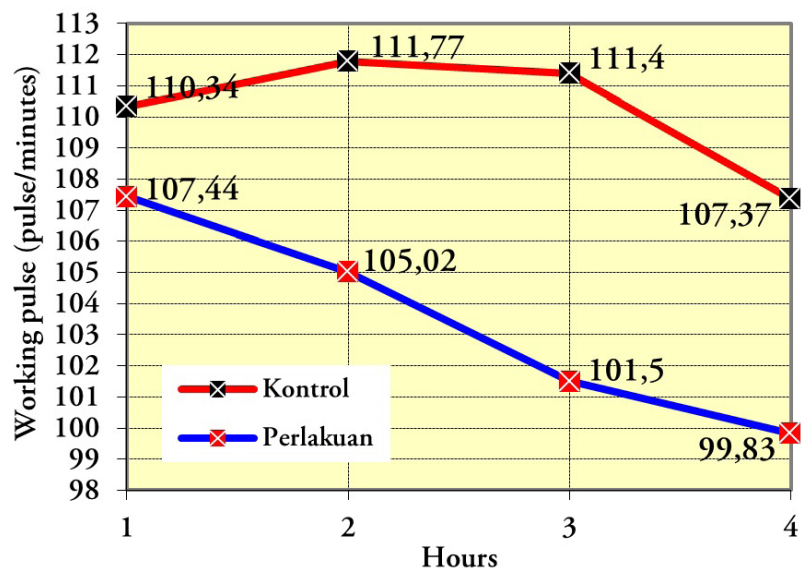

Graph 1. Working pulse of 30 male farmers in Dusun Semaja, Antosari Tabanan.

Table 3. Average working pulse rate before and after treatment of 30 male farmers in Dusun Semaja.

\begin{tabular}{|c|c|c|c|c|c|c|}
\hline \multirow{3}{*}{ Variable } & \multicolumn{4}{|c|}{$\begin{array}{l}\text { Working Pulse } \\
\text { (pulse/minutes) }\end{array}$} & \multirow{3}{*}{$\begin{array}{c}\text { t- } \\
\text { test } \\
\text { paired }\end{array}$} & \multirow{3}{*}{$\mathrm{P}$} \\
\hline & \multicolumn{2}{|c|}{ Control } & \multicolumn{2}{|c|}{ Treatment } & & \\
\hline & Average & SI & Average & SI & & \\
\hline 1. The average & 111,3 & 8,89 & 103,5 & 7,2 & 7,75 & 0,00 \\
\hline 2. Pulse & 37,3 & 10,4 & 30,1 & 8,7 & 6,73 & 0,00 \\
\hline
\end{tabular}

Table 4. The average, standard intersection and the range of ECPT, ECPM, \% CVL and WBGT.

\begin{tabular}{|c|c|c|c|c|c|c|}
\hline \multirow{2}{*}{ Variable } & \multicolumn{2}{|c|}{ Control } & \multicolumn{2}{|c|}{ Treatment } & \multirow{2}{*}{$\begin{array}{l}\text { t-test } \\
\text { paired }\end{array}$} & \multirow{2}{*}{$\mathrm{P}$} \\
\hline & Average & SI & Average & SI & & \\
\hline$E C P T$ & 17,13 & 8,87 & 17,67 & 7,30 & 0,37 & 0,72 \\
\hline$E C P M$ & 24,07 & 7,39 & 21,27 & 5,68 & 2,06 & 0,05 \\
\hline$\% C V L$ & 59,67 & 16,66 & 48,37 & 14,16 & 6,94 & 0,00 \\
\hline$W B G T\left({ }^{\circ} \mathrm{C}\right)$ & 31,40 & 1,39 & 31,34 & 1,36 & 0,72 & 0,24 \\
\hline
\end{tabular}

3. The average of WBGT in control and treatment are; $31.431 .33^{\circ} \mathrm{C}$ and $31.431 .30^{\circ} \mathrm{C}$, there was no significant difference between control and treatment, both in hourly and overall measurements, this means that this study, both control and treatment were exposed to environmental loads. The same one.

\section{Ambient Temperature}

Whereas the environment regarding the average wet, dry, and globe temperatures in every hour of 4 hours carrying out work is shown in the table 5 .

From table 5, several things can be conveyed as follows: dry temperature at control mean $31.52^{\circ} \mathrm{C}$ $1.49^{\circ} \mathrm{C}$ and treatment mean $31.56^{\circ} \mathrm{C} 1.56^{\circ} \mathrm{C}$. Wet temperature $29.83^{\circ} \mathrm{C} 1.37^{\circ} \mathrm{C}$ in treatment $29.93^{\circ} \mathrm{C} 1.48^{\circ} \mathrm{C}$ there was no significant difference between control and treatment. Likewise, with the temperature of the globe, it is slightly higher than the comfortable temperature for Indonesians which ranges from $22-28{ }^{\circ} \mathrm{C}$ with a relative humidity of $70-80 \%$. But still in accordance with the temperature in the dry season in Bali which ranges from $30-31^{\circ} \mathrm{C}$ in the shade and even up to $35.56^{\circ} \mathrm{C}$ in the sun.

\section{Working Tool}

The lampit used in Dusun Semaja, the weight before being attached to a cow is $14 \mathrm{~kg}$ and after being attached to a cow the weight on the back of the lamp is $7 \mathrm{~kg}$. With size specifications according to picture no. 7. After the treatment is added foam pads and a press lever on the lampit stem with the following pictures and sizes:

Table 5. Average, standard deviations and ranges of wet, dry, globe relative humidity.

\begin{tabular}{lccccccc}
\hline \multirow{2}{*}{ Variable } & \multicolumn{2}{c}{ Control } & \multicolumn{3}{c}{ Treatment } & \multirow{2}{*}{ t-test } & $\mathrm{P}$ \\
\cline { 2 - 5 } & Average & SB & Average & SB & paired & \\
\hline $\begin{array}{l}\text { Dry tempe- } \\
\text { rature }\left({ }^{\circ} \mathrm{C}\right)\end{array}$ & 31,52 & 1,49 & 31,56 & 1,31 & 0,30 & 0,38 \\
$\begin{array}{l}\text { Wet tempe- } \\
\text { rature }\left({ }^{\circ} \mathrm{C}\right)\end{array}$ & 29,83 & 1,37 & 29,93 & 1,48 & 0,10 & 0,46 \\
$\begin{array}{l}\text { Globe tem- } \\
\text { perature }\left({ }^{\circ} \mathrm{C}\right)\end{array}$ & 32,80 & 2,72 & 32,46 & 2,12 & 1,56 & 0,06 \\
$\begin{array}{l}\text { Relative hu- } \\
\text { midity }(\%)\end{array}$ & 88,90 & 6,46 & 89,93 & 6,23 & 1,35 & 0,09 \\
\hline
\end{tabular}


a. seat height $=43.30 \mathrm{~cm}$

b. height of the pressure lever $=61.30 \mathrm{~cm}$

The definition of occupational health according to the Health Law of 1992 Article 23 is a work health effort by harmonizing work capacity, workload and work environment so that each worker can work healthily without endangering themselves or the community around them, in order to obtain optimal productivity (Depkes RI, 2006). Capacity, load and work environment are the three main components of occupational health, where interactive and harmonious relationships between the three components will result in good work health and optimal productivity. Good work capacity, such as good work health and nutrition status as well as excellent abilities are needed so that a worker can do a good job. Workload includes physical and mental workload, due to the workload that is too heavy or someone's weak physical ability can cause a worker to suffer from work-related illnesses. Workload in general is influenced by two factors as follows:1. External factors, namely the workload that comes from outside the body. One of them is as a result of the activities carried out. External workload is influenced by: a) physical tasks such as: work station, work attitude, work frequency, muscle work and others, as well as mental work such as: job complexity, demands from work, responsibility for work, load morals and others; b) organization, which concerns how to arrange work and rest time, wage system, work system, work team, rotating work and others; and c) work environment consisting of physical (vibration, noise, radiation, etc.), chemical (toxic, heavy metal, carcinogenic, metal dust, etc.) and biological (viruses, bacteria, fungi, insects, environment, rodents, organic dust and others); 2. Internal factors, namely workload caused by internal factors or originating from the human body, consisting of: a) somatic factors (gender, age, body size, health conditions, nutritional status, etc.) and b) psychological factors (motivation, perceptions, desires, emotions, satisfaction, trust, self-esteem, responsibility and others). To find out the workload, it can be done by measuring the pulse. With the pulse, it will be known the representation of the function of the respirationo- cardiovascular system in fulfilling the body's cells for nutrients and oxygen as a source of energy in carrying out activities. Changes in pulse indicate changes in heart activity, in an attempt to resize nutrients and oxygen to cells that carry out activity (Silverthorn, 2015), in Adiatmika et al., 2007). Cell activity will run optimally if there is enough energy available, namely adenosine triposphate (ATP), the energy obtained through the oxidation of food substances is called aerobic energy, while those obtained without $\mathrm{O} 2$ oxidation are called anaerobic. The end product of the aerobic reaction is $\mathrm{H} 2 \mathrm{O}$ and $\mathrm{CO} 2$, while the anaerobic reaction is lactic acid. Likewise, the breakdown of glucose will result in the formation of 38 ATP, while with anaerobes, where pyruvic acid is not broken down into $\mathrm{CO} 2+\mathrm{H} 2 \mathrm{O}$, but only broken down to lactic acid, the energy available is only enough for the formation of 2 ATP molecules. In addition to very minimal energy, the accumulation of lactic acid will interfere with other processes such as decreased muscle contraction so that it becomes tired. Based on this, it can be said that the heavier an activity of cells/tissues or organs, the increased demand for oxygen and nutrients, so that the heart beats faster, and the pulse rate shows an increase in the frequency of beats per minute. So, the heavier the workload, the more the pulse per minute increases (Adiatmika et al., 2007). According to Rodahl (1989) the physical workload exposed to labour can be measured objectively by: a) direct measurement of the energy requirements required to carry out the work. b) indirectly by recording the pulse during work. Of the two methods, the direct method is the more accurate way, but it can only be used to measure over a certain period (usually only a few minutes), so it cannot be used to describe work operations in general or throughout the day. The indirect method is preferred on the grounds that: continuous pulse recording is possible during work; allows getting a pulse response due to the influence of individual work; easy time recording in accordance with the work activities of each worker. Another way to find out the external load is the Brouha method (Kilbom, 1990; Intaranont and Vanwonterghem, 1993) which is carried out by measuring the resting pulse and recovery pulse 
which is measured shortly after finishing work five times (P1, P2, P3, P4 and P5) and each is measured in 30 seconds and the result is multiplied by two, in this way we can determine the effect of the environment on the body and heat stores in the body:

a. extra cardiac pulse due to metabolism (ECPM);

b. extra cardiac pulse due to heat transfer to periphery (ECPT), with the following formula:

$$
E C P T=\frac{(P 3+P 4+P 5)}{3}-P 0
$$

and

$$
E C P M=(P 1+P 2-P 3)-\frac{(P 3+P 4+P 5)}{3}
$$

Which: $\mathrm{P} 0=$ resting pulse; $\mathrm{P} 1=$ pulse per 30 second from 1st minute of recovery; $\mathrm{P} 2$ = pulse per 30 second from 2nd minute of recovery; $\mathrm{P} 3$ = pulse per 30 second from 3rd minute of recovery; $\mathrm{P} 4=$ pulse per 30 second from 4 th minute of recovery; $\mathrm{P} 5=$ pulse per 30 second from 5 th minute of recovery.

From the results of calculations with this formula, it can be seen: a) ECPT = ECPM, it means that heat caused by environmental factors has the same effect as heat due to metabolic processes produced by body heat; b) ECPT ECPM, it means that there is an external load from the environment to the body; c) ECPM ECPT, it means that the metabolic process is due to the dominant active muscles.

By knowing the value obtained and comparing it with the guidelines above, it can be seen in which direction the improvement efforts will be carried out. While the increase in resting pulse rate to the work rate allowed according to Carlisle (1990) in order to achieve work that can last 8 hours continuously is 35 beats/minute (resting pulse is calculated when sitting), whereas if the resting pulse is calculated when standing, the increase 30 beats/ minute is allowed. From the pulse of recovery, it can also be seen that the workload while doing work includes: 1) the accumulation of heavy workloads from day to day for a long time, so that the heart rate for long recovery does not reach the resting value.; 2) by using the Brouha method the recovery pulse is counted three times (P1, P2 and $\mathrm{P} 3)$ as well as the following: a) if $\mathrm{P} 1-\mathrm{P} 3>10$, and if $\mathrm{P} 1, \mathrm{P} 2$ and $\mathrm{P} 3$ are all below 90, the recovery pulse is normal; b) if the mean of P1 during measurement $<110$, and $\mathrm{P} 1-\mathrm{P} 3>10$, the workload is not excessive; c) if $\mathrm{P} 1-\mathrm{P} 3<10$, and if $\mathrm{P} 3>90$, it means the workload is excessive.

Workload can also be assessed by calculating cardiovascular load (\% CVL) with the Vanwonterghem classification which is based on an increase in work pulse compared to maximum pulse rate (220-age) (Intaranont \& Vanwonterghem, 1993), with the formula as following:

$$
\% \mathrm{CVL}=100 \mathrm{x} \frac{(\mathrm{HRW}-\mathrm{HRr})}{(\mathrm{HRmax} 8 \mathrm{H}-\mathrm{HRr})}
$$

$\mathrm{HRW}$ = average working pulse, $\mathrm{HRr}=$ resting pulse, $\mathrm{HRmax} 8 \mathrm{H}=$ maximum pulse rate allowed for 8 hours of work $\{1 / 3$. (220-age), To find out the workload that arises, the following guidelines are used: a) $00-30 \%$, there is no fatigue and no particular action is required (no particular fatigue, no action requred); b) 30-60\%, needs attention and calculation of the environment (attention level, improvement measurements advised) 60-80\%, requires certain actions within a certain period of time (actions required on short term); c) 80-100\%, immediate action required; d) $100 \%$, work is not allowed (no activity allowed).

\section{Resting Pulse}

The pulse that is measured in a resting state, is known as the resting pulse, the measurement is taken three times in succession, and the result is constant. The subject is measured in a calm state, for that it is better if the subject is sitting or standing or in a sleeping position, then their pulse is measured. In a study where pulse rate is one of the indicators, resting pulse rate is considered as a basic condition that describes the initial condition of the subject (Adiputra, 2002).

\section{Work Rate}

Work pulse is measured when the subject is doing work. The magnitude of the work pulse 
describes the high metabolism of the body at that time (Grandjean \& Kroemer, 1997). Work pulse measurement is carried out during work, if the measuring instrument is possible, but if measurement cannot be carried out every five minutes from the start of work to the end, it can also be measured every 30 minutes or even every one hour of work depending on the type of work performed. Measurement using the ten pulses method (ten pulses method) right at the end of work can and is widely used to describe the work pulse (Adiputra, 2002).

\section{The Pulse of Restoration}

The amount of workload received by workers can also be known by measuring the pulse of recovery, after the worker has finished carrying out work. Since work is stopped, since then the pulse will decrease until it returns to its initial pre-work condition, from the first drop to the initial condition, this pulse is the recovery heart rate (Adiputra, 2002). The recovery rate is usually measured one minute after work is stopped, then resumed at the second, third, fourth and fifth minutes. The recovery rate provides facts about changes in the body's metabolism from an active state to a resting state. By knowing the work pulse, it can be seen the workload being experienced, which is categorized as follows (Bridger, 2008) (Table 6).

The age of the subjects involved in this study was between $24-40$ years with a mean of 33.33 4.83 years. Likewise, the age range for farmers in the study conducted by (Santiana et al., 2018a) was 25 to 45 years. Thus it can be said that the age of farmers in Semaja Village is almost the same as farmers in other places. The body weight of the subjects in Dusun Semaja Antosari Tabanan was

Table 6. Workload categories based on Work Pulse.

\begin{tabular}{lc}
\hline No Workload Category & Range (beats/minute) \\
\hline 1. Light work & 90 \\
2. Moderate work & $90-100$ \\
3. Working heavy & $110-130$ \\
4. Very heavy & $130-150$ \\
5. Extreme & $150-170$ \\
\hline
\end{tabular}

(Quoted from: (Bridger, 2008). in the range of $49-70 \mathrm{Kg}$, with a mean of 56.3 $5.45 \mathrm{Kg}$. Mean height 1643.72 with a range of $155-172 \mathrm{~cm}$. Height and weight are not much different from the height of the farmers in the study conducted by Santiana (2018). According to the Broca index, when viewed from the average height and weight, including the ideal body weight.

Work pulse rate per minute can be used as an indicator of workload. The average resting pulse rate of farmers on the control was 73.07 beats per minute and during operation of the working pulse the average was 110.33 beats per minute. There was an increase in pulse rate of 37.26 beats per minute, this has exceeded the increase in pulse recommended by Grandjean \& Kroeme r(1997), which is 30 beats per minute. Thus, the hope that the work continuity can be carried out for 8 hours continuously is not possible. Likewise, if viewed from the existing workload classification (Table 6), the farmer's workload is considered a heavy workload. This is consistent with research conducted by De \& Sen, 1986 in India, which examined farmers plowing the fields and found that work was included in the moderate to heavy workload category, with a work pulse ranging from 110-130 beats per minute. The research conducted by Yusuf et al., (2016) was about farmers in dealing with, environment temperature changes in Tabanan regency revealed that the working pulse of farmers during the day is 110.50 beats per minute. The increase in the resting pulse rate to the working pulse every hour for four hours is as follows: in the first hour there is an increase of $51 \%$, the second hour is $52.96 \%$, the third one hour is $52.46 \%$ and the fourth hour is $46,89 \%$. Overall, the increase from resting pulse to working pulse was 37.26 beats per minute or $50.99 \%$. Meanwhile, the average difference between resting pulse and working pulse is 37.30 beats per minute.

The average resting pulse rate of farmers after treatment was 73.04 beats per minute and during operation of the working pulse the average was 103.47 beats per minute, an increase of 30.43 beats per minute. This is lower than the provisions put forward by Brouha, 1960, that the combination of workload between the work carried out and the load caused by the environment, should not cause 
an increase in pulse to exceed 110 beats / minute. Thus, the hope that this work will be carried out for 8 hours is still possible. Judging from the existing workload classification (Table 6), it is included in the medium workload. The increase in resting pulse rate to work pulse every hour for four hours is as follows: the first hour there is an increase of $46.38 \%$, the second hour $46.08 \%$, the third one hour $38.28 \%$ and the fourth hour $36 \%$. Overall, there was an increase from rest pulse to work pulse by 30.07 beats per minute or about $40.97 \%$. Meanwhile, the mean difference between resting pulse and working pulse is 30.07 beats per minute.

Paying attention to the increase in the working pulse rate from the resting pulse to the working pulse every hour, there is a difference in the increase in the working pulse starting from the first hour to the last four hours between before treatment and after treatment, as shown in Graph 2. By paying attention to the difference in mean pulses work pulse from rest to work pulse, in control and treatment, it can be said that there is a significant decrease in work pulse with t count $=6.73(\mathrm{p} 0.05)$ or $19.38 \%$ from before treatment. Meanwhile, Sutajaya (Anniza et al., 2017) said that improving working conditions could reduce the work rate by $24.86 \%$. If the pulse is an indicator of the amount of energy the farmer exerts when operating the lampit, it is evident that the lampit operation before the treatment produces more energy than the lampit operation after the treatment.

Operation of the lampit is generally carried out from morning to noon at $700-1100$, so that the effect of the scorching sun cannot be ignored. The workload of farmers, in addition to the main workload (operation of the lamp) is also caused by the body's reaction to resist the additional heat of the sun (Grandjean \& Kroemer, 1997). When combined with the increase in pulse rate (cardiovascular load) with the WBGT index, the environmental conditions before treatment are considered to be heavy work, so it is necessary to have $25 \%$ work and $75 \%$ rest in each working hour (Graph 3).

This is in accordance with the research conducted in the Bali area by Kerana, et al., (1997) regarding the cultivation of rice fields and revealed that this work is included in the moderate to heavy working category so that $50 \%$ work and $50 \%$ rest are needed until it approaches. 25\% work and 75\% rest. It is different from the research conducted by Sutjana (2000) regarding grass-cutting, which is located in Subak Yeh Gde, Kediri District, Tabanan Regency, which reveals that working conditions are included in the mild category and can be carried out for 8 hours continuously.

After the treatment there was a significant decrease in cardiovascular load with $\mathrm{t}$-test count $=$ 6.94 ( $\mathrm{p} 0.05$ ) or $18.94 \%$, so that when combined with the WBGT index, there was a shift in the WBGT graph to the left with the category of moderate work, so that requires $50 \%$ work and $50 \%$ rest (Graph 3). Thus it can also be said that with the addition of foam pads and a pressure lever on the lampitstem, farmers can work longer hours by allocating $50 \%$ working time and $50 \%$ resting time. This occurs because the additional workload arising from the bending posture when pressing and the imperfect weight distribution of the rod can be reduced.

In the control mean\% CVL 59.6716 .66 and treatment\% CVL 48.37 14.16, there was a significant decrease (p 0.05). In the WBGT index graph (graph 4) the cardiovascular load (\% CVL) of control and treatment is included in the moderate category, but the value of $\%$ CVL control is the upper limit of the medium category to the next category, namely the heavy category, whereas after treatment it is almost located at the bottom of the category. moderate. This means that by adding foam pads and a pressure lever, it can be said to reduce cardiovascular load, which means it can also reduce workload. This is in accordance with the research conducted by Suyasning 2006, about women who transport solid stones, able to reduce cardiovascular load (\% CVL) from $101.83 \%$ to $49.77 \%$.

To find out the workload carried out by a person, it can also be seen through the pulse rate of recovery (P1, P2, P3, P4, P5), Santiana (2014) states that the greater the recovery pulse value, especially the P5 value, it means the workload carried out very heavy. For this study, P1, P2 and $\mathrm{P} 3$ on the control mean value 107.15 10.52; 
101.3811 .86 and 94.199 .68 , the treatment mean values were 1087.32 , respectively; 101,188,60 and 97.08 6.00. For P1 and P2, there was no significant difference in both control and treatment ( $p 0.05)$, while for $\mathrm{P} 3$ there was a significant difference (p 0.05). According to the Brouha method (Corlett, 1990), if P1-P3 10 and P3 90, it means that the load that has been received is excessive, so that at minute 3 the pulse value is still above 90 beats per minute. If you look at the formula that refers to changes in the pulse rate caused by metabolism in the body (ECPM), it will be seen that $\mathrm{P} 3$ plays a very decisive role which can cause a scale shift if a comparison is made between ECPT and ECPM. Therefore, it can be understood that the treatment causes a difference in the 3rd recovery pulse (P3) even though the workload received is still equally excessive (P3 90). Pulse recovery P4 and P5 before treatment $90.328 .57 ; 85.928 .52$, after treatment $91.616 .76 ; 84.755 .38$ and there was no significant

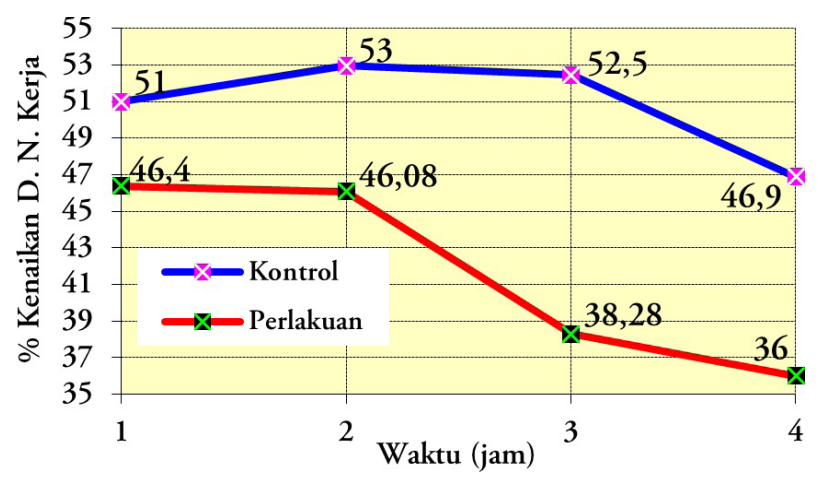

Graph 2. Differences changes in the working pulse of 30 male farmers between the control and treatment groups.

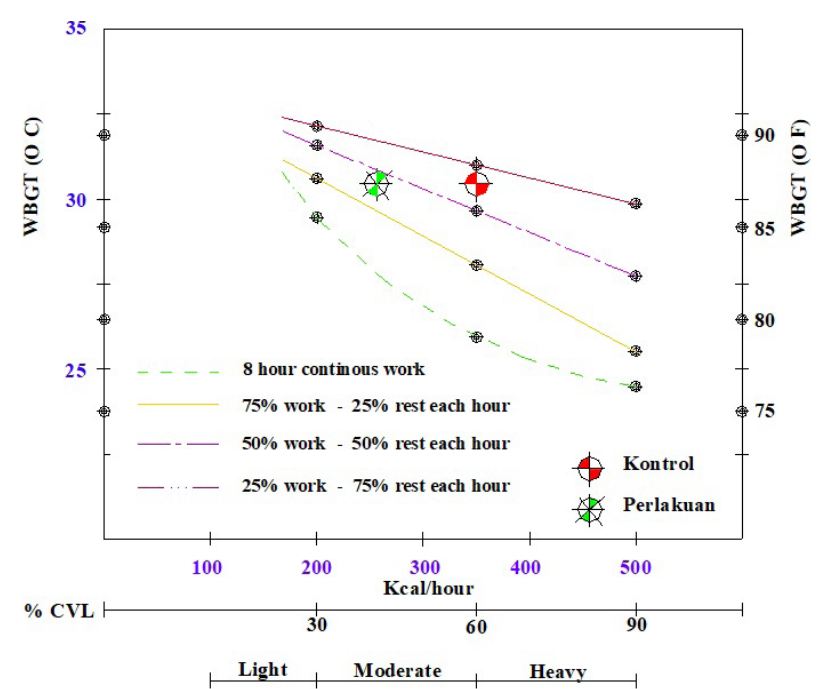

Graph 3. WBGT Index and rest period of 30 male farmers in Semaja. difference ( $\mathrm{p} 0.05)$. but at P5 the recovery pulse value has not equal the resting pulse rate, so it can be said that the load received is still in the heavy category.

ECPT on control 17.138 .87 and ECPT treatment 17.677 .29 , there was no significant difference ( $p$ 0.05). This is not much different from the research conducted by Santiana (2014), regarding the cultivation of paddy soil in the morning with a tractor at Tabanan Bali, with a mean ECPT value of 16.6010 .71 . In ECPM control 24.07 7.39 and ECPM treatment 21.27 5.68 , there was a significant difference (p 0.05). This shows, there is a difference in recovery pulse rate, which means that there is also a difference in workload between before and after repairing the patient.

If we pay attention to the ECPM of control and treatment, both of them are greater than ECPT in both control and treatment, this means that the heat that occurs is due to the metabolic process caused by active muscles is more dominant (Adiputra, 2002). This is consistent with research conducted by (Andewi, 1999) regarding the work attitude of workers at the M.I company in Kediri Tabanan, who found that the increase in heat occurs due to metabolic processes caused by the more dominant role of active muscles.

\section{Conclusion}

From this research it can be concluded, that with the improvement of the lampit, by redesigning the addition of foam pads on the lampit rod can reduce: the workload significantly where the difference in the mean work pulse decreased from 37.30 to 30.07 beats per minute or by 19.38 $\%$; shift in the classification of cardiovascular load from 59.67 to 48.37 , which was 11.30 or $18.94 \%$. In order to reduce the workload and reduce musculoskeletal complaints, it is advisable to farmers to repair the lampit by adding foam pads and a pressure lever on the lampit stem; Even though there was a decrease in workload, chasing jobs were included in moderate to very heavy jobs. Therefore, it is necessary to arrange the time for rest during the work in progress. 


\section{References}

Adiatmika, I. P. G., Manuaba, A., Adiputra, N., \& Sutjana, D. P. (2007). Perbaikan kondisi kerja dengan pendekatan ergonomi total menurunkan keluhan muskuloskeletal dan kelelahan serta meningkatkan produktivitas dan penghasilan perajin pengecatan logam di Kediri-Tabanan. Indonesian Journal of Biomedical Science, 1(3), 224849.

Adiputra, N. (2002). Denyut Nadi dan Kegunaannya dalam Ergonomi. Jurnal Ergonomi Indonesia, 3(1), 22-26.

Andewi, P. J. (1999). Perbaikan Sikap Kerja dengan Memakai Kursi dan Meja Kerja yang Sesuai dengan Data Antropometri Pekerja dapat Meningkatkan Produktivitas Kerja dan Mengurangi Gangguan sistem Musculoskeletal. Thesis Magister, Pascasarjana Universitas Udayana, Denpasar, Bali.

Anniza, M., Tirtayasa, K., \& Muliarta, I. M. (2017). Penambahan Alas Mesin dan Pemberian Peregangan Dinamis di Bagian Proses Pemotongan Singkong Menurunkan Beban Kerja, Keluhan Muskuloskeletal, dan Meningkatkan Produktivitas Kerja pada Industri Keripik Singkong. Jurnal Ergonomi Indonesia (The Indonesian Journal of Ergonomic), 3(1), 29-38.

Bridger, R. (2008). Introduction to ergonomics. Crc Press.

Brouha, L. (1960). Physiology in Industry. Evaluation of Industrial Stresses by the Physiological Reactions of the Worker. Physiology in Industry. Evaluation of Industrial Stresses by the Physiological Reactions of the Worker.

Carlisle, B. (1990). Fitting The Task to the Man: A Textbook of Occupational Ergonomics, By E. Grandjean (Taylor \& Francis, 1988.) [Pp. x+ 363.] Price:£ 3000 (hardback), $\mathfrak{E}$ 13-50 (paperback). International Journal of Production Research, 28(2), 432.

Corlett, N. E. (1990). Static Muscle Loading and the Evaluation of Posture, Evaluation of Human Work: A Practical Ergonomics Methodology, ED: Wilson JR, Corlett NE. Taylor \& Francis,
London.

De, A., \& Sen, R. N. (1986). Ergonomic evaluation of ploughing process of paddy cultivation in India. Journal of Human Ergology, 15(2), 103-112.

Gorgi, K. R. (2019). Revisionist Architecture. Journal of Urban Society's Arts, 6(2), 81-86.

Grandjean, E., \& Kroemer, K. H. E. (1997). Fitting the task to the human: a textbook of occupational ergonomics. CRC press.

Intaranont, K., \& Vanwonterghem, K. (1993). Study of the exposure limits in constraining climatic conditions for strenuous tasks: An ergonomic approach. Unpublished Manuscript, European Commission (DGXII RTD), Brussels, Belgium.

Kilbom, A. (1990). Measurement and assessment of dynamic work. Evaluation of Human Work-A Practical Ergonomic Methodology, 534.

Kirkwood, B. R., \& Sterne, J. A. C. (2010). Essential medical statistics. John Wiley \& Sons.

MS, E. J., \& Ej, M. (1992). Human Factors Engineering Design. National Defense Industry Press.

Rodahl, K. (1989). Physiology of Work. CRC Press. Salokhe, V. M., \& Mamansari, D. U. (1995). Physical workload during selected farm operations. Journal of Human Ergology, 24(2), 161-169.

Santiana, I. M. A., Lokantara, W. D., Yusuf, M., \& Sutapa, I. N. (2018a). Workload Analysis of Rice Field Workers in Bali. 1(Icst), 504-507. https://doi.org/10.2991/icst-18.2018.105

Santiana, I. M. A., Lokantara, W. D., Yusuf, M., \& Sutapa, I. N. (2018b). Workload Analysis of Rice Field Workers in Bali. International Conference on Science and Technology (ICST 2018), 504-507.

Sholahuddin, M. (2014). Urbanisasi Spasial dan Pengaruhnya terhadap Perubahan Struktur Spasial pada Rumah Tinggal (Studi Kasus di Sewon, Bantul, Yogyakarta). Journal of Urban Society's Arts, 1(2), 149-161.

Silverthorn, D. U. (2015). Human physiology. Jones $\&$ Bartlett Publishers.

Sutjana, D. P. (2000). Use of serrated sickle to increase farmer's productivity. Journal of 
Human Ergology, 29 (1-2), 1-6.

Usman, H. (2020). Pengantar Statistika.

Yusuf, M., Adiputra, N., Sutjana, I. D. P., \& Tirtayasa, K. (n.d.). Analisis Beban Kerja Petani pada Pengolahan Lahan Stroberi di Kabupaten Tabanan. JurnalErgonomi Indonesia (The Indonesian Journal of Ergonomic), 2(2), 58-66.

Santiana, A., M. Yusuf. (2014). Evaluasi Beban Kerja Pekerja Pembajak Sawah di Kabupaten Tabanan. Seminar Nasional Idec 2014 Isbn:
978-602-70259-2-9. Surakarta, 20 Mei 2014, 128.

Suyasning, H.I., Nym. Adiputra. (2006). Perbedaan Beban Kerja dan Keluhan Subjektif cara Mengangkut Objek antara Menjunjung, Menggendong di Peunggung dan Menjinjing pada Wanita Bali. Proceeding. Seminar Nasional Ergonomi, Pendekatan Ergonomi Makro untuk Meningkatkan Kinerja Organisasi. Usakti Jakarta: "AQ Print" Graphic Design, Offset Printing \& Material Promotion. 